\title{
"Estimation of thermal characteristics for solar parabolic trough collector in selected locations in Egypt".
}

Prof. Dr. M.A.shaheen, Prof.Assist. Dr. Kh.F.Megalla and Eng. M.G.Saber

University of Helwan, Cairo, Egypt.

\begin{abstract}
Solar Parabolic Trough Collectors (PTCs) are currently used for the production of electricity and applications with relatively higher temperatures, these technologies offer a real alternative to the fossil resources with a little or no environmental impact. In this study, the potential of direct solar irradiance in Egypt and the performance of solar parabolic trough collector (PTC) are estimated under the climate conditions of the country. These two factors are treated as they play an important role in the design of solar thermal plant. In order to determine the most promising solar sites in Egypt, monthly mean daily direct solar radiation have been estimated and compared for different locations corresponding to different climatic region. The study is based on a mathematical modeling of the PTC. Heat balance has been established respectively on the heat transfer fluid (HTF), the absorber tube and the glass envelop using the principle of energy conservation at each surface of the HCE. At first the results for typical days of two seasons; the thermal behavior of the HTF, the absorber and the envelope are obtained. Then to determine the thermal performances of the parabolic trough collector PTC, molten salt (Solar salt) is considered and its temperature, heat gain and other thermal properties evolutions are compared under the topographical and climatic conditions. This analysis is performed with advanced numerical system model which is the system model advisor (SAM) model developed by NREL.
\end{abstract}

Keywords: Solar energy, solar parabolic trough collector, Direct normal solar irradiance, SAM, Heat balance, solar salt performance, Egypt climatic conditions.

\section{Introduction}

Fluctuating oil prices and the uncertainties of future supplies have led to a resonance of interest in alternative energy sources. Where the most important energy type is electrical energy, people are primarily focusing on how to generate electricity. The basic principle to generate electricity is to first produce shaft work, and then use this shaft work to drive a generator. To obtain shaft work, there is a need for an energy conversion system. For countries such as Egypt, solar energy is a potential alternative to oil or coal based sources of electric energy. They are especially appropriate in remote locations not connected to the grid network, such as different places in remote and rural areas in Egypt, where most electrical energy is derived by diesel generators [1]. As the amount of energy needed gets higher, the population increases. The risk of global warming associated with the emission of greenhouse gases during the combustion of fossil fuels is driving research in the efficient use of energy and renewable energy sources [2]. In a study carried by Greenpeace, it has been found that the use of concentrating solar power (CSP) can prevent the emission of 154 million tons of 
$\mathrm{CO}_{2}$ by 2020. Just one 50MWel parabolic trough power plant can cut the annual heavy oil consumption by 30 million litters and thus eliminate 90.000 tons of $\mathrm{CO}_{2}$ emissions [3].

\section{NOMENCLATURE}

$\mathrm{a}=$ accommodation coefficient of annulus gas

$\mathrm{A}_{\mathrm{cs}, \mathrm{b}}=$ minimum cross-section of receiver support bracket $\left[\mathrm{m}^{2}\right]$

$\mathrm{b}=$ interaction coefficient of annulus gas

$\mathrm{C}, \mathrm{m}, \mathrm{n}=$ constants

$\mathrm{D}_{2}=$ inside diameter of absorber pipe $[\mathrm{m}]$

$\mathrm{D}_{3}=$ outside diameter of absorber pipe $[\mathrm{m}]$

$\mathrm{D}_{4}=$ inside diameter of glass envelope $[\mathrm{m}]$

$\mathrm{D}_{5}=$ outside diameter of glass envelope $[\mathrm{m}]$

$\mathrm{f}=$ Darcy friction factor

$\mathrm{f}_{2}=$ friction factor for the inner surface of the absorber pipe

$\mathrm{g}=$ gravitational constant, $9.81 \mathrm{~m} / \mathrm{s}^{2}$

$\mathrm{h}_{1}=$ convection heat transfer coefficient for the HTF at $\mathrm{T}_{1}\left[\mathrm{~W} / \mathrm{m}^{2}-\mathrm{K}\right]$

$\mathrm{h}_{34}=$ convection heat transfer coefficient of annulus gas at $\mathrm{T}_{34}\left[\mathrm{~W} / \mathrm{m}^{2}-\mathrm{K}\right]$

$\mathrm{h}_{56}=$ convection heat transfer coefficient of air at $\mathrm{T}_{56}\left[\mathrm{~W} / \mathrm{m}^{2}-\mathrm{K}\right]$

$\bar{h}_{b} \quad=$ convection heat transfer coefficient of air evaluated at the average receiver support bracket film temperature $\left[\mathrm{W} / \mathrm{m}^{2}-\mathrm{K}\right]$

$\mathrm{K}=$ incident angle modifier

$\mathrm{k}_{1}=$ thermal conductance of $\mathrm{HTF}$ at $\mathrm{T} 1[\mathrm{~W} / \mathrm{m}-\mathrm{K}]$

$\mathrm{k}_{23}=$ thermal conductance of absorber wall at $\mathrm{T}_{23}[\mathrm{~W} / \mathrm{m}-\mathrm{K}]$

$\mathrm{k}_{34}=$ thermal conductance of annulus gas at $\mathrm{T}_{34}[\mathrm{~W} / \mathrm{m}-\mathrm{K}]$

$\mathrm{k}_{56}=$ thermal conductance of air at $\mathrm{T}_{56}[\mathrm{~W} / \mathrm{m}-\mathrm{K}]$

$\mathrm{k}_{\mathrm{b}}=$ conduction heat transfer coefficient of air evaluated at the average receiver

support bracket film temperature [W/m-K]

$\mathrm{k}_{\mathrm{std}}=$ thermal conductance of annulus gas at standard temperature and pressure

$[\mathrm{W} / \mathrm{m}-\mathrm{K}]$

$m=$ mass flow rate $[\mathrm{kg} / \mathrm{s}]$

$\mathrm{Nu}_{\mathrm{D} 2}=$ Nusselt number of HTF based on $\mathrm{D}_{2}$

$\mathrm{Nu}_{\mathrm{D} 5}=$ Nusselt number of air based on $\mathrm{D}_{5}$

$\mathrm{P}_{\mathrm{a}}=$ annulus gas pressure $[\mathrm{mmHg}]$

$\mathrm{P}_{\mathrm{b}}=$ exterior perimeter of receiver support bracket $[\mathrm{m}]$

$\mathrm{P}_{\mathrm{r} 1}=$ Prandtl number of HTF evaluated at $\mathrm{T}_{1}$

$\mathrm{P}_{\mathrm{r} 2}=$ Prandtl number of HTF evaluated at $\mathrm{T}_{2}$

$\mathrm{Pr}_{34}=$ Prandtl number of annulus gas at $\mathrm{T}_{34}$

$\operatorname{Pr}_{5}=$ Prandtl number of air at $\mathrm{T}_{5}$

$\operatorname{Pr}_{56}=$ Prandtl number for air at $\mathrm{T}_{56}$

$\mathrm{Pr}_{6}=$ Prandtl number of air at $\mathrm{T}_{6}$

$\mathrm{q}^{\prime}{ }_{12 \mathrm{conv}}=$ convection heat transfer rate between the heat transfer fluid and inside

wall of the absorber pipe per unit receiver length $[\mathrm{W} / \mathrm{m}]$

$\mathrm{q}^{\prime \prime} 23$ cond $=$ conduction heat transfer rate through the absorber pipe wall per unit

receiver length $[\mathrm{W} / \mathrm{m}]$

$\mathrm{q}^{\prime} 3$ SolAbs $=$ solar irradiation absorption rate into the absorber pipe per unit receiver length $[\mathrm{W} / \mathrm{m}]$

$q^{\prime \prime} 34$ conv $=$ convection heat transfer rate between the outer surface of the absorber pipe to the inner surface of the glass envelope per unit receiver length [W/m]

$\mathrm{q}^{\prime \prime}{ }_{34 \mathrm{rad}}=$ radiation heat transfer rate between the outer surface of the absorber pipe

to the inner surface of the glass envelope per unit receiver length $[\mathrm{W} / \mathrm{m}]$

$q^{\prime}{ }^{\prime} 7_{\mathrm{rad}}=$ radiation heat transfer rate between the outer surface of the glass envelope

to the sky per unit receiver length [W/m]

$\mathrm{q}^{\prime \prime} 45$ cond $=$ conduction heat transfer rate through the glass envelope per unit receiver length $[\mathrm{W} / \mathrm{m}]$

$\mathrm{q}^{\text {“ }}{ }_{\text {SSolAbs }}=$ solar irradiation absorption rate into the absorber pipe per unit receiver length per unit receiver length $[\mathrm{W} / \mathrm{m}]$

$\mathrm{q}^{\prime}{ }_{56 \mathrm{conv}}=$ convection heat transfer rate between the outer surface of the glass envelope to the atmosphere per unit receiver length $[\mathrm{W} / \mathrm{m}]$ $\mathrm{q}{ }^{`}$ Cond,bracket $=$ conductive heat loss through each receiver support bracket [W]

$\mathrm{q}^{\prime}$ HeatLoss $=$ total heat loss rate from the heat collecting element to the surroundings $[\mathrm{W} / \mathrm{m}]$

$\mathrm{q}_{\mathrm{si}}{ }_{\mathrm{si}}=$ solar irradiation per receiver length $[\mathrm{W} / \mathrm{m}]$

$\mathrm{Ra}_{\mathrm{D} 3}=$ Rayleigh number of annulus gas based on $\mathrm{D}_{3}$

$\mathrm{Ra}_{\mathrm{D} 5}=$ Rayleigh number of air based on $\mathrm{D}_{5}$

$\mathrm{Re}_{\mathrm{D} 2}=$ Reynolds number of HTF based on $\mathrm{D}_{2}$

$\mathrm{Re}_{\mathrm{D} 5}=$ Reynolds number of air based on $\mathrm{D}_{5}$

$\mathrm{T}_{1}=$ mean (bulk) temperature of the $\mathrm{HTF}\left[{ }^{\circ} \mathrm{C}\right]$

$\mathrm{T}_{2}=$ absorber pipe inner surface temperature $\left[{ }^{\circ} \mathrm{C}\right]$

$\mathrm{T}_{23}=$ average absorber wall temperature, $\left(\mathrm{T}_{2}+\mathrm{T}_{3}\right) / 2\left[{ }^{\circ} \mathrm{C}\right]$

$\mathrm{T}_{3}=$ absorber pipe outer surface temperature $\left[{ }^{\circ} \mathrm{C}\right]$

$\mathrm{T}_{34}=$ average temperature of annulus gas, $\left(\mathrm{T}_{3}+\mathrm{T}_{4}\right) / 2\left[{ }^{\circ} \mathrm{C}\right]$

$\mathrm{T}_{4}=$ glass envelope inner surface temperature $\left[{ }^{\circ} \mathrm{C}\right]$

$\mathrm{T}_{5}=$ glass envelope outer surface temperature $\left[{ }^{\circ} \mathrm{C}\right]$

$\mathrm{T}_{56}=$ average temperature of air, $\left(\mathrm{T}_{5}+\mathrm{T}_{6}\right) / 2\left[{ }^{\circ} \mathrm{C}\right]$

$\mathrm{T}_{6}=$ atmosphere temperature $\left[{ }^{\circ} \mathrm{C}\right]$

$\mathrm{T}_{7}=$ estimated effective sky temperature $\left[{ }^{\circ} \mathrm{C}\right]$

$\mathrm{T}_{\text {base }}=$ temperature at base of receiver support bracket $\left[{ }^{\circ} \mathrm{C}\right]$

$\mathrm{L}_{\mathrm{HCE}}=\mathrm{HCE}$ length $(\mathrm{m})$

\section{Greek letters}

$\alpha_{56}=$ thermal diffusivity of air at T56 $\left[\mathrm{m}^{2} / \mathrm{s}\right]$

$\alpha_{\text {abs }}=$ absorptance of the absorber selective coating

$\alpha_{\text {env }}=$ absorptance of the glass envelope

$\beta=$ volumetric thermal expansion coefficient of annulus gas or air $[1 / \mathrm{K}]$

$\delta=$ molecular diameter of annulus gas $[\mathrm{cm}]$

$\varepsilon=$ equivalent surface roughness $[\mathrm{m}]$

$\varepsilon_{\#}^{\prime}=$ optical efficiency terms

$\varepsilon_{3}=$ emissivity of absorber selective coating

$\varepsilon_{4}=$ emissivity of inner surface of glass envelope

$\varepsilon_{5}=$ emissivity of outer surface of glass envelope

$\gamma=$ ratio of specific heats of annulus gas

$\eta_{\text {abs }}=$ effective optical efficiency at the absorber

$\eta_{\text {env }}=$ effective optical efficiency at the glass envelope

$\lambda=$ mean-free-path between collisions of a molecule of annulus gas $[\mathrm{cm}]$

$\pi=$ ratio of the circumference to diameter of a circle, 3.14159

$\sigma=$ Stefan-Boltzmann constant $\left[\mathrm{W} / \mathrm{m}^{2}-\mathrm{K}^{4}\right]$

$\tau_{\text {env }}=$ transmittance of the glass envelope

$\Theta=$ The solar incidence angle, ${ }^{\circ}$

\section{Acronyms}

$\mathrm{CSP}=$ concentrating solar power

$\mathrm{HCE}=$ Heat Collection Element

$\mathrm{SCA}=$ Solar Collector Assembly

PTC $=$ parabolic trough collector

SEGS = solar energy generating systems

$\mathrm{HTF}=$ heat transfer fluid

$\mathrm{DNI}=$ direct normal irradiance

DISS $=$ direct solar steam

IAM = incidence angle modifier

$\mathrm{ASE}=$ Archimede Solar Energy

NREL = National Renewable Energy Laboratory

PSA = Plataforma Solar de AlmeÍa

The solar energy incident on the Earth surface is about 10.000 times the world energy demand. Fortunately Egypt lies on the north eastern side of Africa, bordered on its northern coast by the Mediterranean Sea and on its eastern coast by the Red Sea. It comprises an area of about one million $\mathrm{km}^{2}$, made up as follows: Nile valley and delta about $4 \%$ of the total; Eastern desert area about 22\%; Western desert area about 68\%; and the Sinai Peninsula area about 6\% [4]. There is a trend in Egypt to apply solar thermal power plants to meet the requirements of industry, tourism, petroleum, electricity, health and reconstruction. It is well 
known that Egypt region has significant and unique importance due to its certain strategic site near the North Eastern borders of Africa. The field of solar thermal application systems requires a complete knowledge and detailed analysis about the potentiality of the site for solar radiation activity and in order to deliver high temperatures with good efficiency, a high performance solar collector is required, systems with light structures and low cost technology for process heat application up to $500{ }^{0} \mathrm{C}$ could be obtained with solar parabolic trough collector PTC.

PTC heat transfer analyzes have received increasing attention since 1980. Forristall [5] has described the development, the validation, and the use of a heat transfer model implemented in Engineering Equation Solver (EES). Numerical simulations of thermal and fluid-dynamic behavior of a single-pass and double-pass solar parabolic trough collector have been carried out by Garcia-Valladares and Velazquez [6]. Their results have shown that the double-pass can enhance the thermal efficiency compared with the single-pass. A coupled simulation method based on MCRT and Finite Volume Method (FVM) has been presented by He et al. [7] to solve the complex coupled heat transfer problem of radiation, heat conduction and convection in PTC system. The heat transfer and fluid flow performance in the LS-2 collector tube has been investigated to validate the coupled simulation model. Vasquez Padella et al. [8] have studied a 1-D numerical heat transfer analysis of a PTC. The receiver and envelope have been divided into several segments and mass and energy balance have been applied in each segment. The results obtained have shown good agreement with experimental data. Dongqiang et al. [9] have examined overall heat loss, end loss and thermal emittance of the coating of a newly designed receiver of PTC in order to evaluate its thermal characterization. A heat loss comparison between Solel UVAC3, Schott 2008 PTR70, and Himin PTR-2011 showed that the new receiver had very good thermal performance and distinctly decreased heat loss in the parabolic trough solar field. Cheng et al. [10] have used the same method as He et al. [7] to analyze the total photo-thermal conversion process of an experimental LS-2 PTC system. The numerical results have been compared to the experimental data and good agreement has been obtained. Reddy and Harinarayana [11] have estimated the solar thermal energy potential in India with $1^{\circ}$ interval in a grid manner. The energy generation ranges from $600 \mathrm{MWh}$ to $2600 \mathrm{MWh}$ annually for parabolic trough technology of 1 MWe capacity plant using TRNSYS model. Jignasha Bhutka, Jaymin Gajjar, T. Harinarayana [12] modified the design of $1 \mathrm{MW}$ operational power plant installed at Gurgaon using Parabolic Trough Collector (PTC) technology. The results are compared with the expected output of Gurgaon power plant and also 50MW power plant at Rajasthan. the results have closely matched with a small deviation of $3.1 \%$ and $3.6 \%$ for Gurgaon and Rajasthan plants, respectively. Charlain-Joel Ngangoum Keou, Donatien Njomo1, Vincent Sambou, A. R. Andrianaharinjaka Finiavana, Ahmadou Diaby Tidiane [13] compute direct solar radiation based on monthly average Linke turbidity factor and various tracking modes in two chosen sites in the far north region of Cameroon. Also, a detailed two dimensional numerical heat transfer analysis of a PTC has been performed. Direct solar irradiation, ambient temperature, optical and thermal analyses of the collector receiver takes into consideration all modes of heat transfer and the nonlinear algebraic equations were solved simultaneously at each instant during a day of computation using Engineering Equation Solver (EES). Evangelos Bellos and Christos Tzivanidis [14] study developed analytical 
expressions for the determination of the thermal performance of parabolic trough collectors. The non-linear equations of the energy balances in the parabolic trough collector device are simplified using suitable assumptions. The final equation set includes all the possible parameters which influence the system performance and it can be solved directly without computational cost. This model is validated using experimental literature results. Zouhir Leemrani, Salma Marrakchi, Hassan Asselman, Adel Asselman [15]. Their paper consists of a theoretical study based on the conversion of solar energy into thermal energy using the parabolic trough collector. The main objective is to study the performance of this collector in the region of the North-West of Morocco. The methodology is based on the resolution of heat exchange equations by a numerical simulation using the Matlab software to study the performance of the parabolic collector under the local climate of the region. Mohammed Hasan Abbood, Mohammed Mohsen Mohammed. [16] make an experimental testing shows the construction and testing of three parabolic trough solar collectors (PTSC) experimentally in order to produce moderate-temperature steam. The experimental investigation was carried out on PTSC to testing the thermal performance of the system. The tests were carried out at University of Kerbala / college of engineering with climatic conditions (32.34 o N, 44.03 o E) for nine days during the month of July and August of 2018.

In this paper we will estimate the thermal characteristics for two axes tracking solar parabolic trough collector using SAM, through study the potential of direct solar irradiance in some selected locations in Egypt (Aswan, El Giza and Marsa Matruh) and the performance of solar parabolic trough collector (PTC) under the climate conditions of these locations will be estimated, where these two factors are treated as they play an important role in the design of solar thermal power plant.

So, the present work is divided into two parts. The first one consists in the study a mathematical model on the HCE and the second part analysis the equations and relationships used in the HCE performance model in advanced numerical system model which is the system model advisor (SAM) model developed by NREL (National Renewable Energy Laboratory). The receiver (HCE's) formulation used in the SAM model uses a 1-dimensional model developed in Forristall's work uses the Engineering Equation Solver (EES) package that is designed to evaluate complex systems of equations using an iterative approach. The system of equations describe the relationship between temperature and heat loss: The surface temperature of the absorber tube is a function of the heat absorption, while convective and radiative losses are strong functions of surface temperature. Convective loss is directly proportional to the difference between receiver surface and ambient temperatures, and radiation loss is proportional to temperature difference to the fourth power. The performance of the receiver can't be accurately modeled using simple explicit relationships. Instead, System Advisor uses implicit equations, solving iteratively with successive substitution until the solution converges. In this model, the climatic and topographical conditions specific to the area under study have been taken into account by exploiting the direct solar radiation, the temperature change, HTF heat gain and heat losses in the selected locations in order to study the influence of the climatic conditions and solar radiation on the performances of the PTC. To improve the results presentation a combination of NREL's System Advisor Model (SAM) and Excel spreadsheets will be used. 


\section{Estimation of the hourly and daily direct normal solar irradiance in Egypt}

Estimating the direct normal solar irradiance (DNI) is of great importance in the development of concentrating solar power plant technologies. The estimation of the direct normal solar irradiance (DNI) allows the identification of the most suitable sites available for deploying the solar parabolic trough collector plants. In this paper we are focus on three Egyptian governorates (Aswan, El-Giza and Marsa Matruh) which differ on their weather and latitudes. The analysis of a solar energy system design is typically established by predicting its performance over a "typical" "clear" day. Many clear-day mathematical solar irradiance models may be used to predict the expected maximum hourly DNI. Hottel has presented a model, with good accuracy and simple use, to estimate the clear-day transmittance of direct solar radiation through clear sky. Hottel's clear-day model of direct normal solar irradiance is based on atmospheric transmittance calculations for four different climate zones in the globe using Standard Atmosphere [17].

For two axes tracking, we have compared the DNI for summer and winter typical day in 21 June and 21 December for Aswan see Figure (1) and Figure (2), they are show results for direct solar irradiance per unit of collector area, $\left(\mathrm{w} / \mathrm{m}^{2}\right)$ for the location of Aswan (latitude +24.091 - longitude +32.897 - altitude $106 \mathrm{~m}$ ). Figure (1) represents a typical summer clear day and Figure (2) represents a typical winter clear day. Figure (1) shows that the maximum amount of the direct solar irradiance for the two axes tracking is collected at time $12.00 \mathrm{pm}$ by $912.7 \mathrm{w} / \mathrm{m}^{2}$. Figure (2) shows that the maximum amount of the direct solar irradiance for the two axes tracking is collected at time $10.00 \mathrm{pm}$ by $643 \mathrm{w} / \mathrm{m}^{2}$.

The monthly mean daily direct solar radiation with two axes tracking apertures in Aswan is Cleary shown in Figure (3). It shows that monthly mean daily direct solar radiation varies from $18.6 \mathrm{MJ} / \mathrm{m}^{2} /$ day to $32.2 \mathrm{MJ} / \mathrm{m}^{2} /$ day as a maximum value achieved in July. We report in Figure (4) the monthly mean daily direct solar radiation for a two-axis tracking system at three typical locations in Egypt namely, Aswan, El-Giza, and Marsa Matruh, these locations correspond to different climatic regions. Figure (4) shows that the monthly mean direct solar radiation varies for these locations from $8.3 \mathrm{MJ} / \mathrm{m}^{2} /$ day to $32.2 \mathrm{MJ} / \mathrm{m}^{2} /$ day which this maximum value is achieved in Aswan in July and $31.2 \mathrm{MJ} / \mathrm{m}^{2} /$ day For El-Giza governorate in June. Knowledge of solar radiation potential enables us to derive information about the performance of solar energy systems for the cities studied and possibly elsewhere with similar climatic conditions.

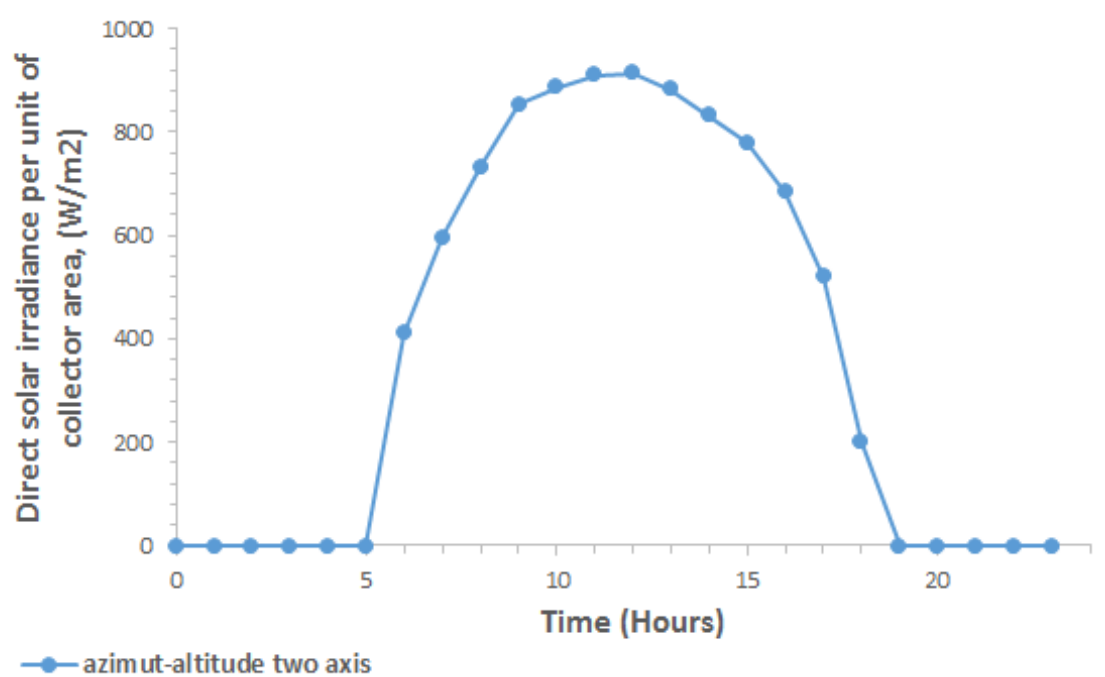


Figure (1) Clear-day direct solar irradiance for two axes tracking system for Aswan on June 21 


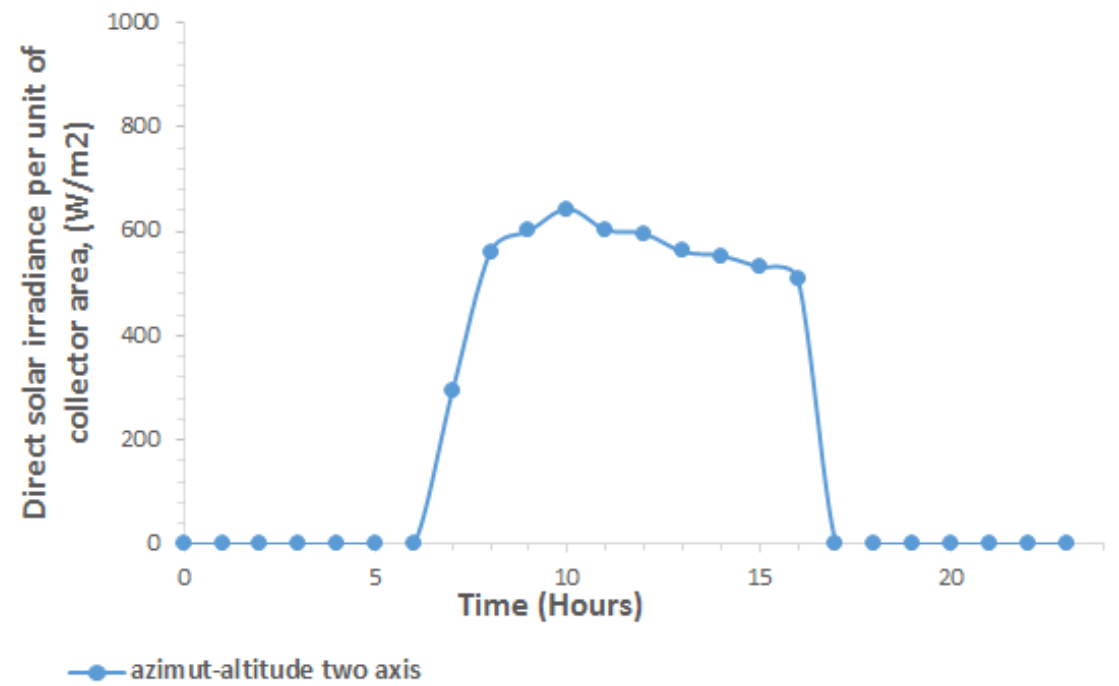

Figure (2) Clear-day direct solar irradiance for two axes tracking system for Aswan on Dec 21

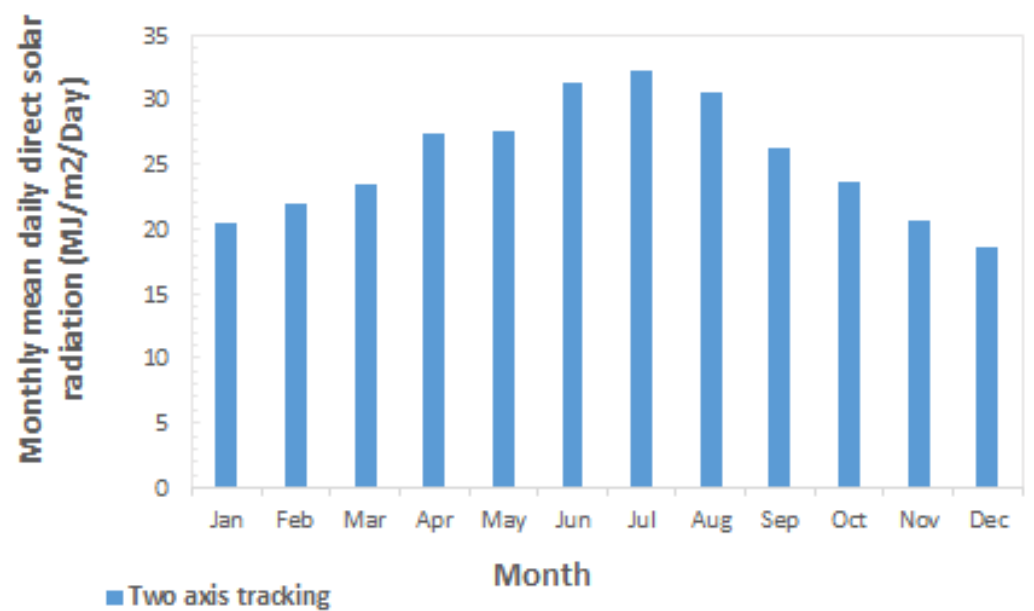

Figure (3) Monthly mean daily direct solar radiation for two axis tracking system in Aswan

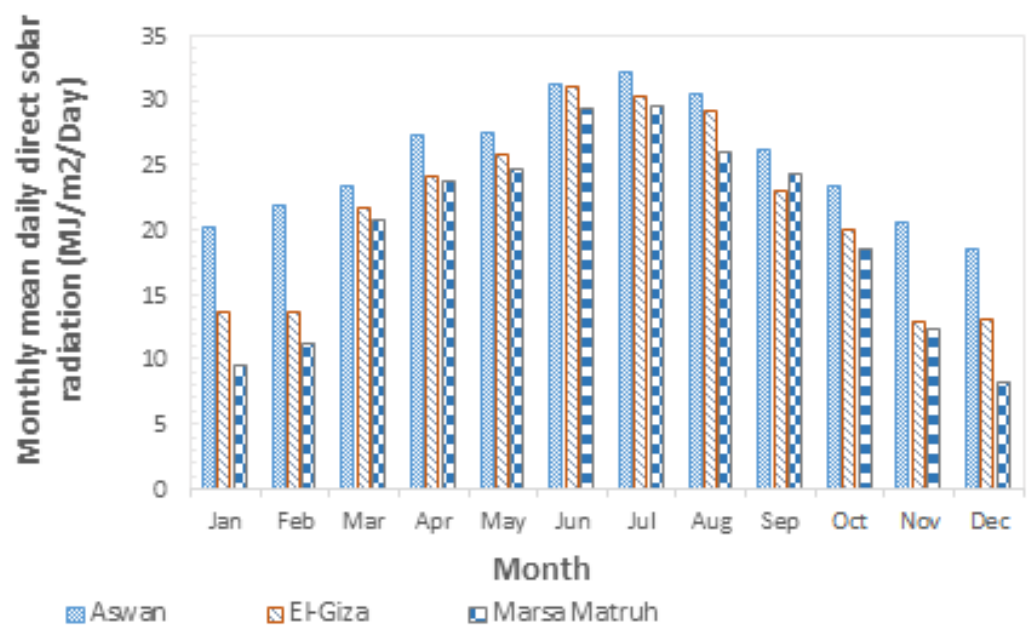

Figure (4) Monthly mean daily direct solar radiation for two axis tracking system for different locations in Egypt 


\section{Heat balance model of the parabolic trough collector}

The HCE performance model is based on an energy balance about the collector and the HCE. The energy balance includes the direct normal solar irradiation incident on the collector, optical losses from both the collector and HCE, thermal losses from the HCE, and the heat gain into the HTF. For short receivers up to $100 \mathrm{~m}$ a one-dimensional energy balance gives reasonable results; for longer receivers a two dimensional energy balance becomes necessary [19]. In our study the one-dimensional energy balance are applicable where the receiver under study is a short receiver. All the equations and relationships used in the one dimensional HCE performance model are described below. The following assumptions have been made in the mathematical model:

(1) One dimensional flow. (2) Vacuum is considered in the annular space. (3) Constant diameters and concentrator surfaces. (4) Conduction losses at the ends of each trough are considered. (5) The solar PTC has two-axis tracking system that perfectly follows the sun during the day.

The HCE performance model uses an energy balance between the HTF and the atmosphere, and includes all equations and correlations necessary to predict the terms in the energy balance, which depend on the collector type, HCE condition, optical properties, and ambient conditions. Figure (5) shows the one-dimensional steady-state energy balance for a crosssection of an HCE, with the glass envelope intact, and Figure (6) shows the thermal resistance model and subscript definitions. For clarity, the incoming solar energy and optical losses have been omitted from the resistance model. The optical losses are due to imperfections in the collector mirrors, tracking errors, shading, and mirror and HCE cleanliness. The effective incoming solar energy (solar energy minus optical losses) is absorbed by the glass envelope (q.`5SolAbs) and absorber selective coating (q.`3SolAbs). Some energy that is absorbed into the selective coating is conducted through the absorber (q. ${ }^{2} 23 \mathrm{cond}$ ) and transferred to the HTF by convection( . $^{-}{ }_{12 \text { conv }}$ ); remaining energy is transmitted back to the glass envelope by convection (q. ${ }^{\prime}{ }_{34 \mathrm{conv}}$ ) and radiation (q.'34rad) and lost through the HCE support bracket through conduction (q. ${ }^{-}$Cond,bracket). The energy from the radiation and convection then passes through the glass envelope by conduction (q. $45 \mathrm{cond}$ ) and along with the energy absorbed by the glass envelope (q. ${ }^{`}$ Solabs) is lost to the environment by convection (q. ${ }_{56 \mathrm{conv}}$ ) and radiation (q. ${ }^{5}$ 7 $\mathrm{rad}$ ) [19]. With the help of Figures $(5,6)$. The energy balance equations are determined by conserving energy at each surface of the HCE crosssection as follows:

With the glass envelope:

$$
\begin{aligned}
& \mathrm{q}^{\prime \prime 12 \text { conv }}=\mathrm{q}^{\prime \prime 23 \text { cond }} \\
& q^{\prime \prime} 3 \text { SolAbs }=q^{\prime \prime} 34 \text { conv }+q^{\prime \prime} 34 \text { rad }+q^{\prime \prime} 23 \text { cond }+q^{\prime \prime} \text { Cond,bracket } \\
& \mathrm{q}^{\prime \prime} 34 \mathrm{conv}+\mathrm{q}^{\prime \prime} 34 \mathrm{rad}=\mathrm{q}^{\prime \prime} 45 \mathrm{cond} \\
& \mathrm{q}^{\prime \prime}{ }_{45 \mathrm{cond}}+\mathrm{q}^{\prime}{ }_{5 \text { SolAbs }}=\mathrm{q}^{\prime}{ }_{56 \mathrm{conv}}+\mathrm{q}^{\prime}{ }_{57 \mathrm{rad}} \\
& \mathrm{q}^{\prime \prime} \text { HeatLoss }=\mathrm{q}^{\prime \prime} 56 \mathrm{conv}+\mathrm{q}^{\prime \prime} \text { 57rad }+\mathrm{q}^{\prime \prime} \text { Cond,bracket }
\end{aligned}
$$




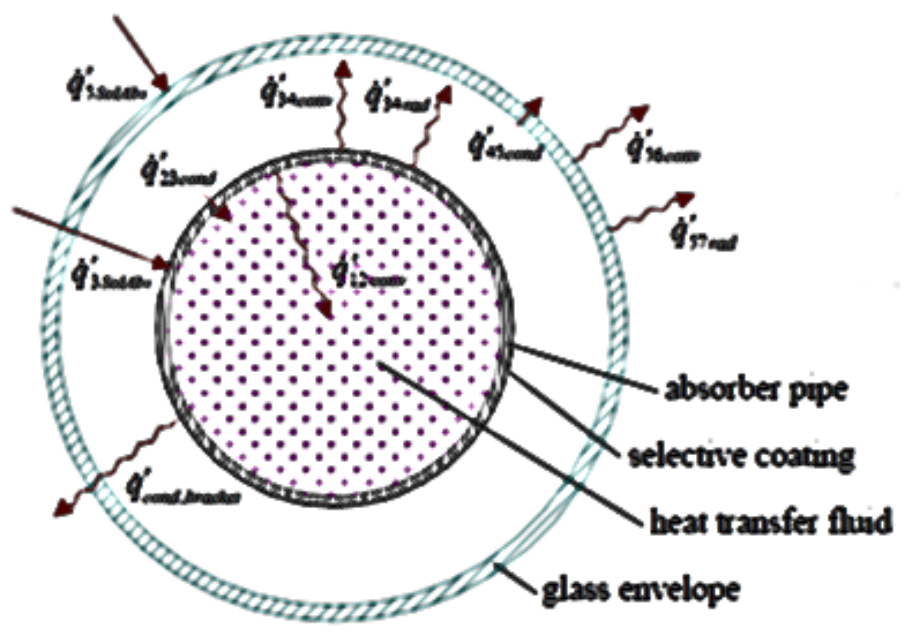

Figure (5) Heat transfer plant for a solar PTC

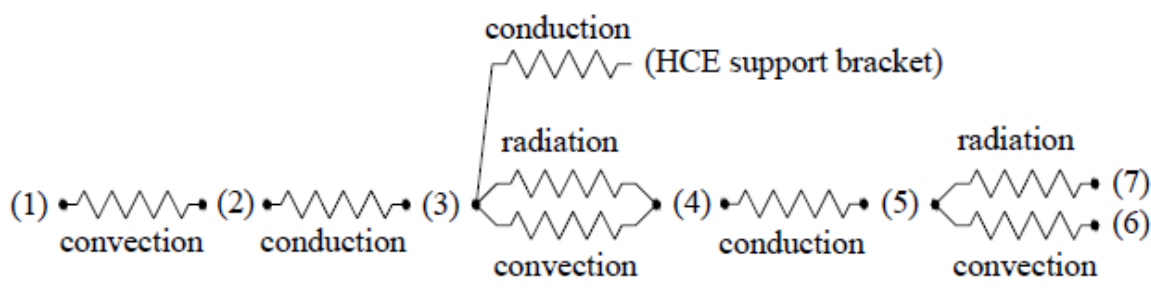
(1) heat transfer fluid
(5) glass envelope outer surface
(2) absorber inner surface
(3) absorber outer surface
(4) glass envelope inner surface
(6) surrounding air
(7) sky

Figure (6) Thermal resistance model for a cross-section of an HCE

- Convection Heat Transfer between the HTF and the Absorber

From Newton's law of cooling, the convection heat transfer from the inside surface of the absorber pipe to the HTF is

With,

$$
\dot{\mathrm{q}}_{12 \text { couv }}^{\prime}=h_{1} D_{2} \pi\left(T_{2}-T_{1}\right)
$$

$$
h_{1}=N u_{D 2} \frac{k_{1}}{D_{2}}
$$

The Nusselt number depends on the type of flow through the HCE. At typical operating conditions, the flow is well within the turbulent region and the following number correlation developed by Gnielinski $[20,21]$ is used. However, during off-solar hours or when evaluating the HCE heat losses on a test platform, the flow in the HCE may become transitional or laminar because of the viscosity of the HTF at lower temperatures. When the laminar option is chosen and the Reynolds number is lower than 2300 , the Nusselt number will be constant. For pipe flow, the value will be 4,36 [20].

With,

$$
N u_{D 2}=\frac{f_{2} / 8\left(\mathrm{Re}_{D 2}-1000\right) \mathrm{Pr}_{1}}{1+12.7 \sqrt{f_{2} / 8}\left(\mathrm{Pr}_{1}^{2 / 3}-1\right)}\left(\frac{\mathrm{Pr}_{1}}{\mathrm{Pr}_{2}}\right)^{0.11}
$$

$$
f_{2}=\left(1.82 \log _{10}\left(\operatorname{Re}_{D 2}\right)-1.64\right)^{-2}
$$


- Conduction Heat Transfer through the Absorber Wall

Fourier's law of conduction through a hollow cylinder describes the conduction heat transfer through the absorber wall [Incropera and DeWitt 1990]-[20].

$$
\dot{q}_{23 \text { cond }}^{\prime}=2 \pi k_{23}\left(T_{2}-T_{3}\right) / \ln \left(D_{3} / D_{2}\right)
$$

In this equation the conduction heat transfer coefficient is constant, and is evaluated at the average temperature between the inner and outer surfaces. The conduction coefficient depends on the absorber material type. Using absorber material type 304L the conduction coefficient is:

$$
k_{23}=(0.013) T_{23}+15.2
$$

- Heat Transfer from the Absorber to the Glass Envelope for the annulus gas

Convection and radiation heat transfer occur between the absorber and the glass envelope. The convection heat transfer mechanism depends on the annulus pressure [KJCOC 1993][22]. When the HCE annulus is under vacuum (pressure $<\sim 1$ torr), the convection heat transfer between the absorber and glass envelope occurs by free-molecular convection [Ratzel et al.1979]-[20].

With,

$$
\dot{q}_{34 \text { conv }}^{\prime}=\pi D_{3} h_{34}\left(T_{3}-T_{4}\right)
$$

$$
\begin{aligned}
& h_{34}=\frac{k_{\text {std }}}{\left(D_{3} / 2 \ln \left(D_{4} / D_{3}\right)+b \lambda\left(D_{3} / D_{4}+1\right)\right)} \\
& b=\frac{(2-a)(9 \gamma-5)}{2 a(\gamma+1)} \\
& \lambda=\frac{2.331 E(-20)\left(T_{34}+273.15\right)}{\left(P_{a} \delta^{2}\right)}
\end{aligned}
$$

\section{- Radiation Heat Transfer}

The radiation heat transfer between the absorber and glass envelope (q. $34 \mathrm{rad}$ ) is estimated with the following equation [Incropera and DeWitt 1990]-[20].

$$
\dot{q}_{34 \text { rad }}^{\prime}=\frac{\sigma \pi D_{3}\left(T_{3}{ }^{4}-T_{4}{ }^{4}\right)}{\left(1 / \varepsilon_{3}+\left(1-\varepsilon_{4}\right) D_{3} /\left(\varepsilon_{4} D_{4}\right)\right)}
$$

\section{- Conduction Heat Transfer through the Glass Envelope}

The conduction heat transfer through the glass envelope uses the same equation as the conduction through the absorber wall described above. As in the absorber case, the temperature distribution is assumed to be linear. Furthermore, the thermal conductance is assumed constant - as explained above - with a value of 1.04 (Pyrex ${ }^{\circledR}$ glass) [Touloukian and DeWitt 1972]. 
- Heat Transfer from the Glass Envelope to the Atmosphere

The heat will transfer from the glass envelope to the atmosphere by convection and radiation. The convection will either be forced or natural, depending on whether there is wind. Radiation heat loss occurs due to the temperature difference between the glass envelope and sky.

- Convection Heat Transfer

The convection heat transfer from the glass envelope to the atmosphere (q. ${ }_{56 \text { conv }}$ ) is the largest source of heat loss, especially if there is a wind. From Newton's law of cooling.

$$
\begin{aligned}
& \dot{q}_{56 \text { conv }}^{\prime}=h_{56} \pi D_{5}\left(T_{5}-T_{6}\right) \\
& h_{56}=\frac{k_{56}}{D_{5}} N u_{D 5}
\end{aligned}
$$

The Nusselt number depends on whether the convection heat transfer is natural (no wind) or forced (with wind).

1. No Wind Case

If there is no wind, the convection heat transfer from the glass envelope to the environment will be by natural convection. For this case, the correlation developed by Churchill and Chu will be used to estimate the Nusselt number [Incropera and DeWitt 1990]-[20].

$$
\begin{aligned}
& \bar{N} u_{D 5}=\left\{0.60+\frac{0.387 R a_{D 5}{ }^{1 / 6}}{\left[1+\left(0.559 / \mathrm{Pr}_{56}\right)^{9 / 16}\right]^{8 / 27}}\right\}^{2} \\
& R a_{D 5}=\frac{g \beta\left(T_{5}-T_{6}\right) D_{5}{ }^{3}}{\left(\alpha_{56} v_{56}\right)} \\
& \beta=\frac{1}{T_{56}} \\
& \operatorname{Pr}_{56}=\frac{v_{56}}{\alpha_{56}}
\end{aligned}
$$

This correlation is valid for $10^{5}<\mathrm{Ra}_{\mathrm{Do}}<10^{12}$, and assumes a long isothermal horizontal cylinder. Also, all the fluid properties are determined at the film temperature, $\left(\mathrm{T}_{5}+\mathrm{T}_{6}\right) / 2$.

2. Wind Case

If there is wind, the convection heat transfer from the glass envelope to the environment will be forced convection. The Nusselt number in this case is estimated with Zhukauskas' correlation for external forced convection flow normal to an isothermal cylinder [Incropera and DeWitt 1990]-[20].

With,

$$
\bar{N} u_{D 5}=C \operatorname{Re}_{D 5}{ }^{m} \operatorname{Pr}_{6}{ }^{n}\left(\frac{\mathrm{Pr}_{6}}{\operatorname{Pr}_{5}}\right)^{1 / 4}
$$

\begin{tabular}{|c|c|c|}
\multicolumn{1}{c}{$\mathbf{R e}_{\mathbf{D}}$} & $\mathbf{C}$ & $\mathbf{m}$ \\
\hline $1-40$ & 0.75 & 0.4 \\
\hline $40-1000$ & 0.51 & 0.5 \\
\hline $1000-200000$ & 0.26 & 0.6 \\
\hline $200000-1000000$ & 0.076 & 0.7 \\
\hline
\end{tabular}


And,

$$
\begin{gathered}
\mathrm{n}=0.37, \text { for } \operatorname{Pr}<=10 \\
\mathrm{n}=0.36, \text { for } \operatorname{Pr}>10
\end{gathered}
$$

This correlation is valid for $0.7<\operatorname{Pr}_{6}<500$, and $1<\operatorname{Re}_{\mathrm{D} 5}<10^{6}$. All fluid properties are evaluated at the atmospheric temperature, $\mathrm{T}_{6}$, except $\mathrm{Pr}_{5}$, which is evaluated at the glass envelope outer surface temperature.

- Radiation transfer between the glass envelope and sky [Incropera and DeWitt 1990]-[20].

$$
\dot{q}_{57 \mathrm{rad}}^{\prime}=\sigma D_{5} \pi \varepsilon_{5}\left(T_{5}{ }^{4}-T_{7}{ }^{4}\right)
$$

- Solar Irradiation Absorption in the Glass Envelope: The solar absorption into the glass envelope is treated as a heat flux to simplify the model.

$$
\begin{aligned}
& \dot{q}_{5 \text { SolAbs }}^{\prime}=\dot{q}_{s i}^{\prime} \eta_{e w} \alpha_{e v v} \\
& \eta_{e w}=\varepsilon_{1}^{\prime} \varepsilon_{2}^{\prime} \varepsilon_{3}^{\prime} \varepsilon_{4}^{\prime} \varepsilon_{5}^{\prime} \varepsilon_{6}^{\prime} \rho_{c l} K \\
& K=\cos (\theta)+0.000884 \theta-0.00005369 \theta^{2}
\end{aligned}
$$

- Solar Irradiation Absorption in the Absorber: The solar energy absorbed by the absorber occurs very close to the surface; therefore, it is treated as a heat flux. The equation for the solar absorption in the absorber becomes

$$
\begin{gathered}
\dot{q}_{3 \text { SolAbs }}^{\prime}=\dot{q}_{s i}^{\prime} \eta_{a b s} \alpha_{a b s} \\
\eta_{a b s}=\eta_{e n v} \tau_{e n v}
\end{gathered}
$$

$\eta_{\text {env }}$ is the same value shown above. Again, all terms are assumed to be independent of temperature.

- Heat Loss through HCE Support Bracket

The bracket heat loss is estimated with the following equation [Incropera and DeWitt 1990][20]

$$
\dot{q}_{\text {cond ,bracket }}^{\prime}=\sqrt{\bar{h}_{b} P_{b} k_{b} A_{c s, b}}\left(T_{\text {base }}-T_{6}\right) / L_{H C E}
$$

\section{Algorithm}

To determine the thermal characterizations of the HCE system, the system of linear equations obtained above has been solved using the physical trough model included into SAM (System advisor model), where the receiver (HCE) formulation used in the physical trough model uses a 1-dimensional model developed in [11]. Forristall's work uses the Engineering Equation Solver (EES) package [23] that is designed to evaluate complex systems of equations using an iterative approach. The performance of the receiver can't be accurately modeled using simple explicit relationships. Instead, System Advisor uses implicit equations, 
solving iteratively with successive substitution until the solution converges. The physical trough model characterizes many of the system components from first principles of heat transfer and thermodynamics.

- The physical trough model uses physical properties including the temperature, specific heat, density, viscosity, and conductivity values have been taken at the HTF saturation pressure for different temperatures.

- The chosen heat transfer fluid (HTF) is the solar salt $\left(60 \% \mathrm{NaNO}_{3}\right.$ and $\left.40 \% \mathrm{KNO}_{3}\right)$; it can be used over a temperature range of $260^{\circ} \mathrm{C}$ to approximately $621^{\circ} \mathrm{C}$. As temperature decreases, the salts start to crystallize at $238^{\circ} \mathrm{C}$.

- We consider in our study to produce $100 \mathrm{MWe}$.

- The number of solar multiple will be 2, the row spacing will be default is 15 meters, stow angle is 170 degrees, number of field subsections will be 2, Header pipe roughness (m) will be $4.57 \mathrm{e}-05$, the HTF pump efficiency will be taken as default 0.85 , the Freeze protection temp $\left({ }^{\circ} \mathrm{C}\right.$ ) will be $220^{\circ} \mathrm{C}$ and the irradiation at design will be $950 \mathrm{w} / \mathrm{m}^{2}$, so the calculated solar field area is 575 acres with total land area 806 acres when we take the number of SCA / HCE assemblies per loop to be 14, Figure (7).

- The chosen collector is Luz LS-3 type (Table-1), with two axis tracking system and with a vacuum in the annulus space between the absorber and the glass envelope, where the annulus gas is air with pressure of $0.01 \mathrm{mmHg}$. The Luz LS-3 installed in SEGS VII - IX, Kramer Junction, California [24].

The chosen Receiver is Solel UVAC 3 type (Table-1), which is the newest HCE available as of May 2008 [24].

- Ambient Conditions include direct normal solar irradiance, wind speed, ambient temperature from the selected location for clear days from different seasons of the year.

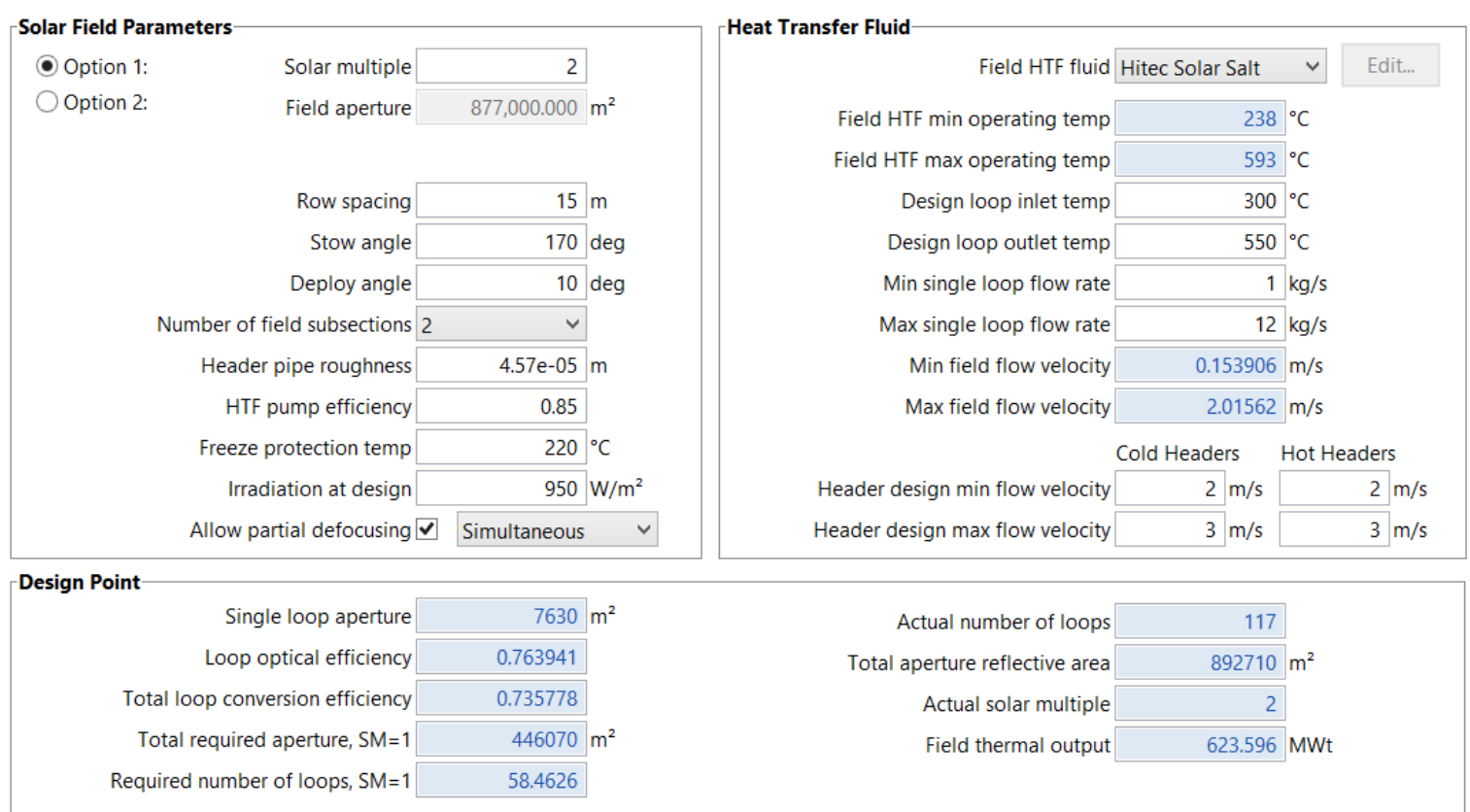

Figure (7) SAM solar field window 


\section{Table (1) Solar PTC specification used in the model}

\begin{tabular}{|l|c|}
\hline Luz Ls3 collector specification & \\
\hline Aperture width & $5.75 \mathrm{~m}$ \\
\hline Length of collector & $100 \mathrm{~m}$ \\
\hline Focal distance & $2.11 \mathrm{~m}$ \\
\hline Tracking error & 0.99 \\
\hline Geometry effects & 0.98 \\
\hline Mirror reflectance & 0.935 \\
\hline IAM & 1 \\
\hline Dirt on mirror & 0.97 \\
\hline General optical error & 0.99 \\
\hline Solel UVAC3 receiver specification & \\
\hline Absorber tube inner diameter & $0.066 \mathrm{~m}$ \\
\hline Absorber tube outer diameter & $0.07 \mathrm{~m}$ \\
\hline Glass envelope inner diameter & $0.115 \mathrm{~m}$ \\
\hline Glass envelope outer diameter & $0.121 \mathrm{~m}$ \\
\hline Internal surface roughness & $4.5 \times 10^{-5}$ \\
\hline Absorber flow pattern & Tube flow \\
\hline Absorber material type & $304 \mathrm{~L}$ \\
\hline Absorber absorptance & 0.96 \\
\hline Absorber emittance & Function in T( $\left.{ }^{\circ} \mathrm{C}\right)$ \\
\hline Envelope absorptance & 0.02 \\
\hline Envelope emittance & 0.86 \\
\hline Envelope transmittance & 0.96 \\
\hline Bellows shadowing & 0.971 \\
\hline Dirt on receiver & 0.98 \\
\hline
\end{tabular}

\section{Results discussion and Validation:}

\section{- Results discussion}

Simulation results of the outlet temperature of the solar salt, of the absorber and of the glass envelope for typical days in the daylight period in clear sky are presented in figure (8) and figure (9). The solar salt heat gain and heat loss per unit length of receiver with time in hours around the day is also presented in figure (10) and figure (11).

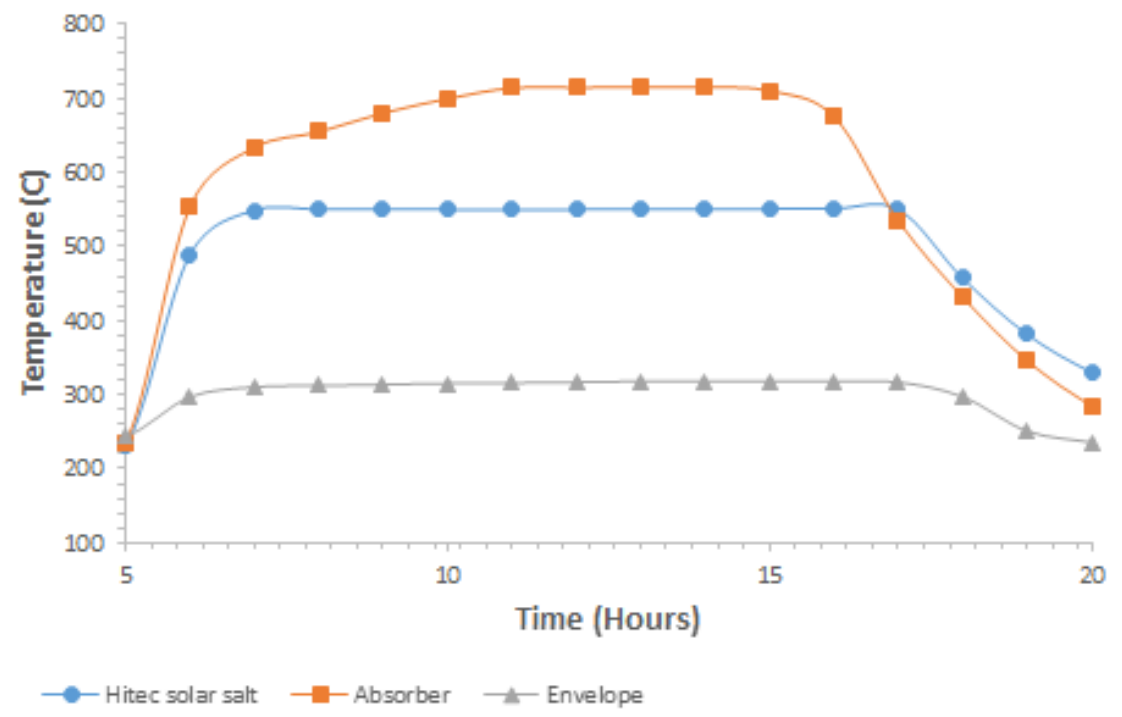

Figure (8) Hitec solar salt, absorber and glass envelope temperatures over SCA for Aswan on June 21 


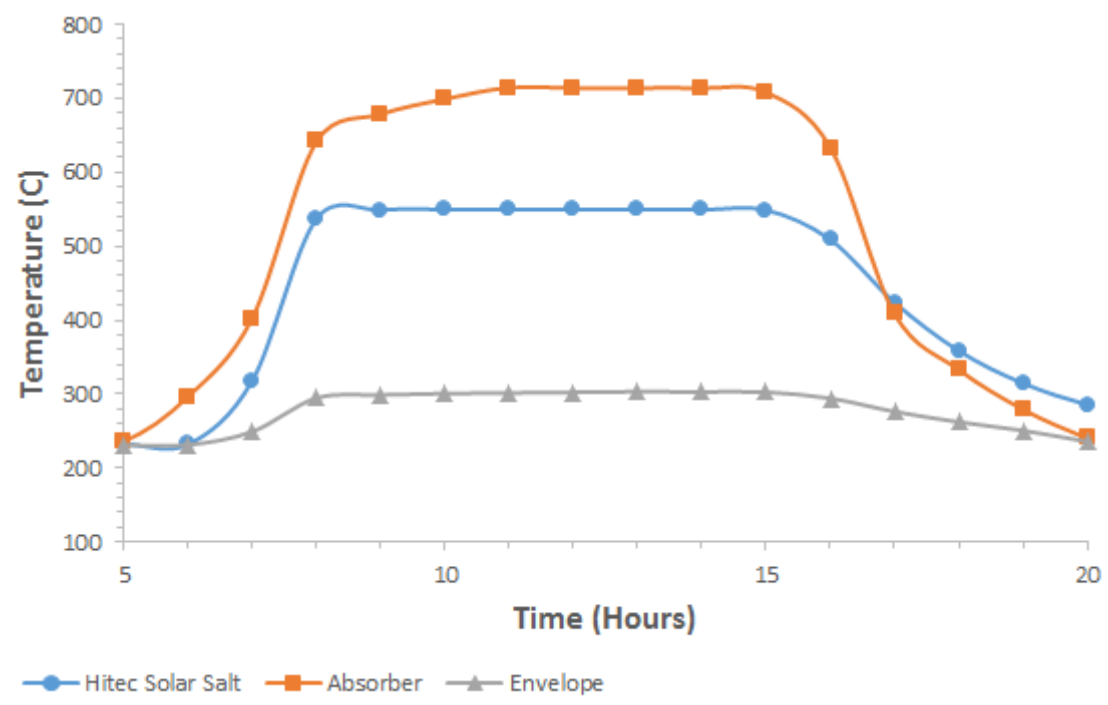

Figure (9) Hitec solar salt, absorber and glass envelope temperatures over SCA for Aswan on Dec. 21

Figure (8) and figure (9) represent the variation of the temperatures of the solar salt, of the absorber and of the envelope as a function of time for typical days of the year (summer and winter). We observed that the temperature of the heat transfer fluid exceeds $550^{\circ} \mathrm{C}$ from $8 \mathrm{~h} 00$ to $17 \mathrm{~h} 00$ in June and nearly to $550^{\circ} \mathrm{C}$ from $9 \mathrm{~h} 00$ to $15 \mathrm{~h} 00$ in December. The absorber temperature exceeds $650^{\circ} \mathrm{C}$ from $8 \mathrm{~h} 00$ to $16 \mathrm{~h} 00$ to reach $715.3^{\circ} \mathrm{C}$ at $13 \mathrm{~h} 00$ in June and exceeds $650^{\circ} \mathrm{C}$ from $9 \mathrm{~h} 00$ to $15 \mathrm{~h} 00$ in December. In the same way the envelope temperature exceeds $300^{\circ} \mathrm{C}$ from $7 \mathrm{~h} 00$ to $17 \mathrm{~h} 00$ to reach $318^{\circ} \mathrm{C}$ at $13 \mathrm{~h} 00$ in June and exceeds $300^{\circ} \mathrm{C}$ from $10 \mathrm{~h} 00$ to $15 \mathrm{~h} 00$ to reach $303.3^{\circ} \mathrm{C}$ at $13 \mathrm{~h} 00$ in December.

We observe in figures (10) and (11) that the evolution heat gain per unit length of receiver is variant around the day from sunrise to sunset periods to reach the maximum value 1619 $\mathrm{w} / \mathrm{m}^{2}$ at $13 \mathrm{~h} 00$ in June, then it starts to drop during the day and it reaches maximum value $1050 \mathrm{w} / \mathrm{m}^{2}$ at $10 \mathrm{~h} 00$ in December. And observe that the heat loss also variant with solar time. The plots also indicate that the heat losses are lower in the winter than the summer. This is because the plants typically operate at lower HTF temperatures during the winter when energy demand is lower. It can be seen also that the heat loss follows perfectly the temperature profile of the absorber. The More the temperature difference between the absorber and the ambient is important, the more the heat loss towards the outside increases, resulting in reduction in heat gain.

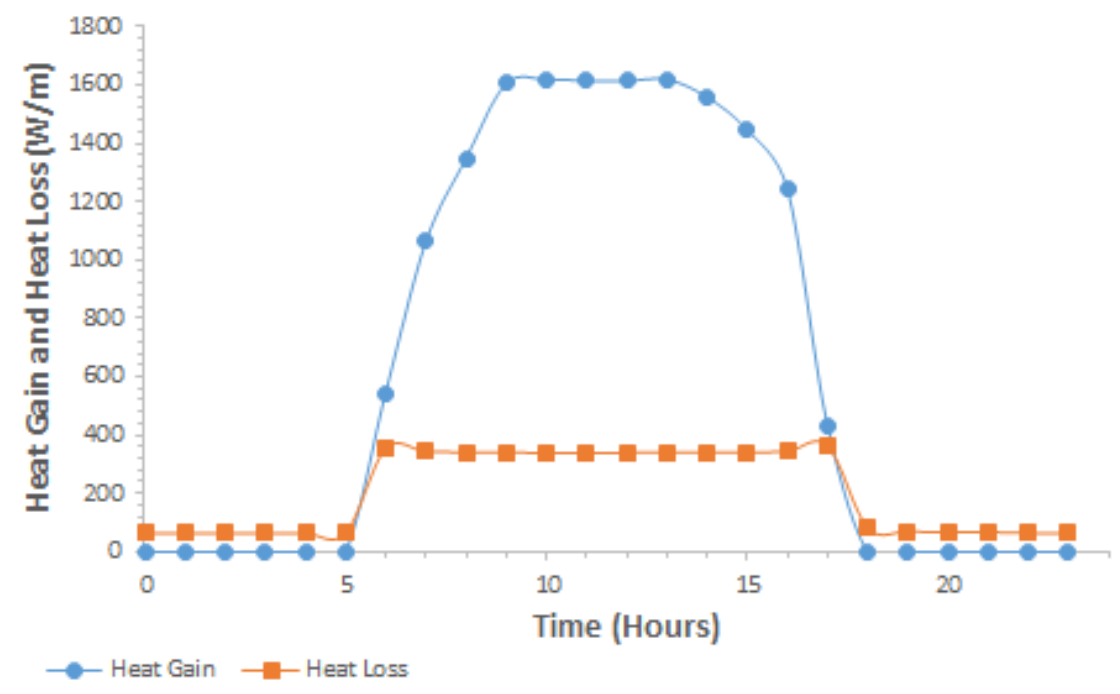

Figure (10) Heat gain and heat loss for Aswan on June 21 


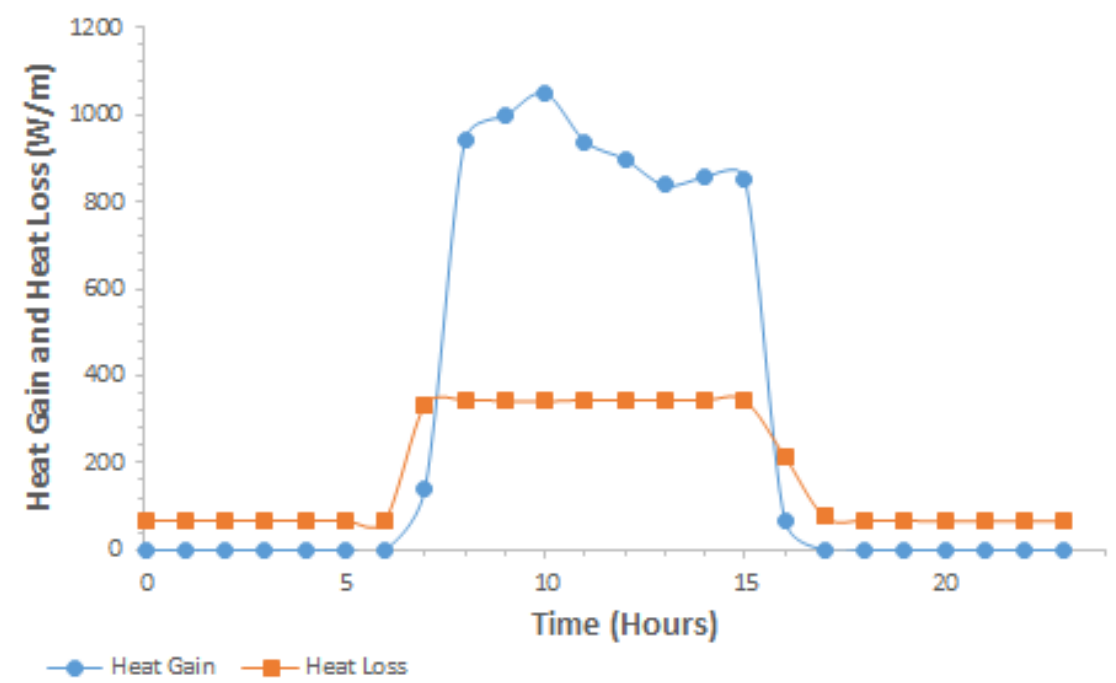

Figure (11) Heat gain and heat loss for Aswan on Dec. 21

We consider the heat transfer fluid thermal properties in our results which effect on the evaluation of the PTC. The below figures (12-15) represent the thermal behavior of the solar salt with temperature compared to Syltherm 800. We noticed from these figures that the four physical properties (Density, specific heat, viscosity and thermal conductivity) influence the temperature evolution of the fluid. The solar salt has maximum range of temperature compared to other molten salts or thermal oils, so the solar salt has the most important density and thermal conductivity.

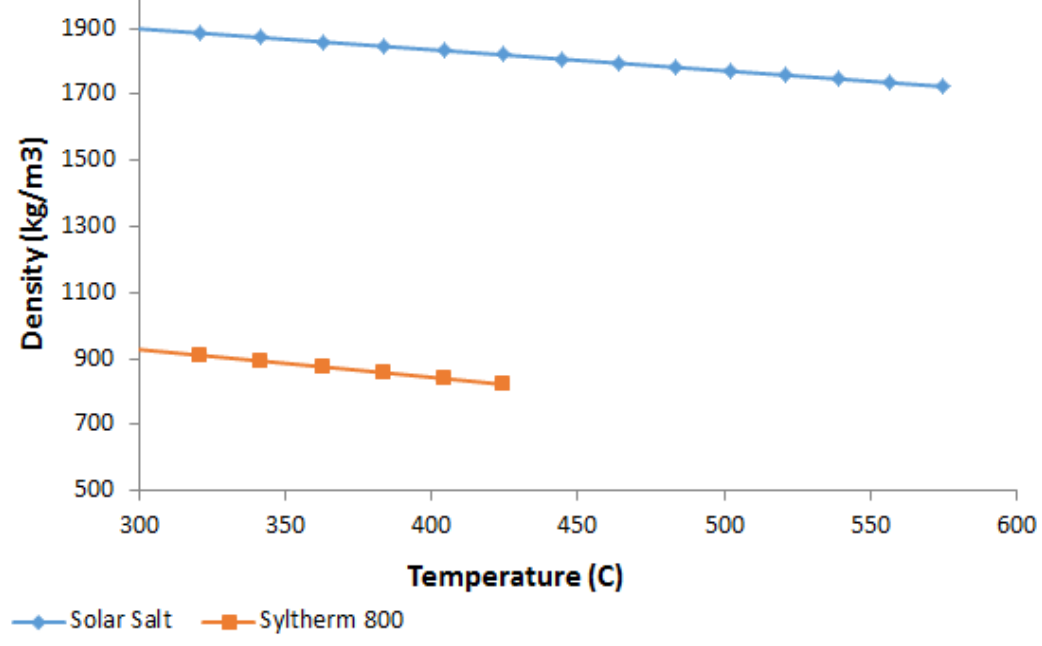

Figure (12) Hitec Solar Salt density with temperature vs. Syltherm 800

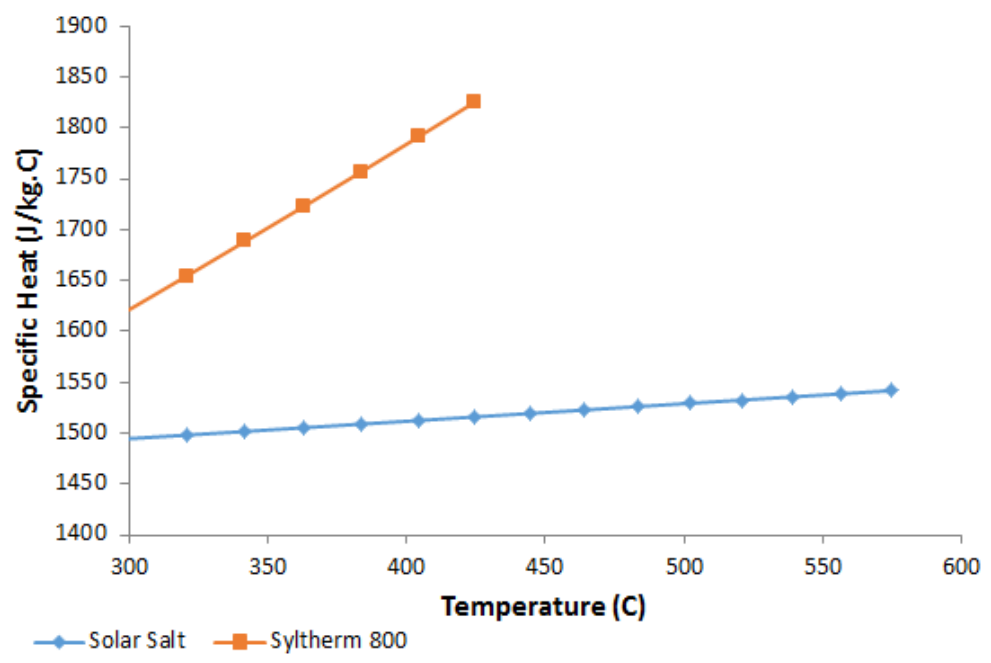

Figure (13) Hitec Solar Salt specific heat with temperature vs. Syltherm 800 


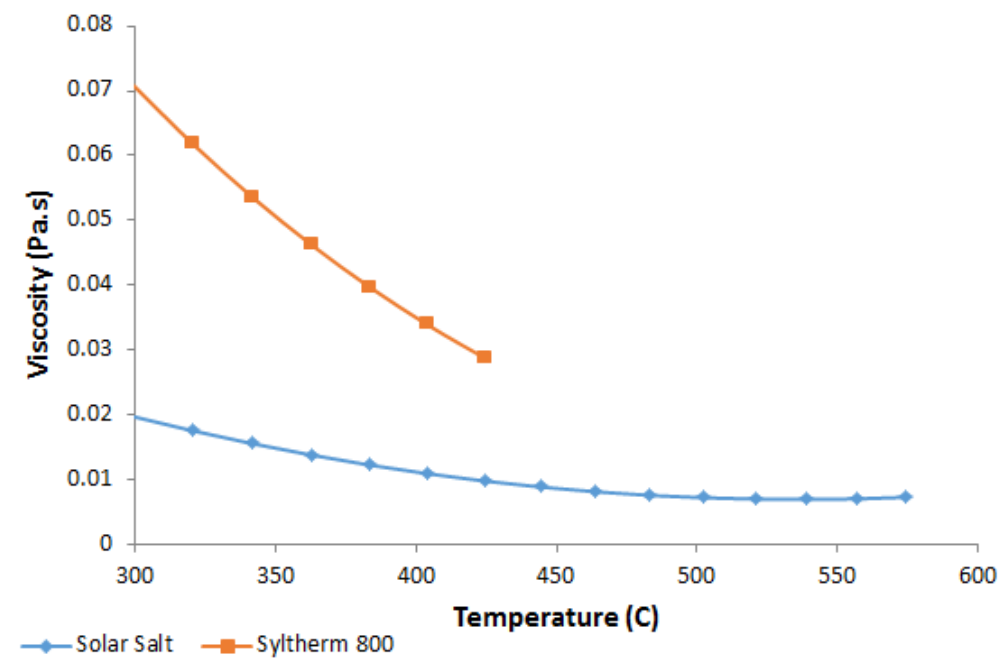

Figure (14) Hitec Solar Salt Viscosity with temperature vs. Syltherm 800

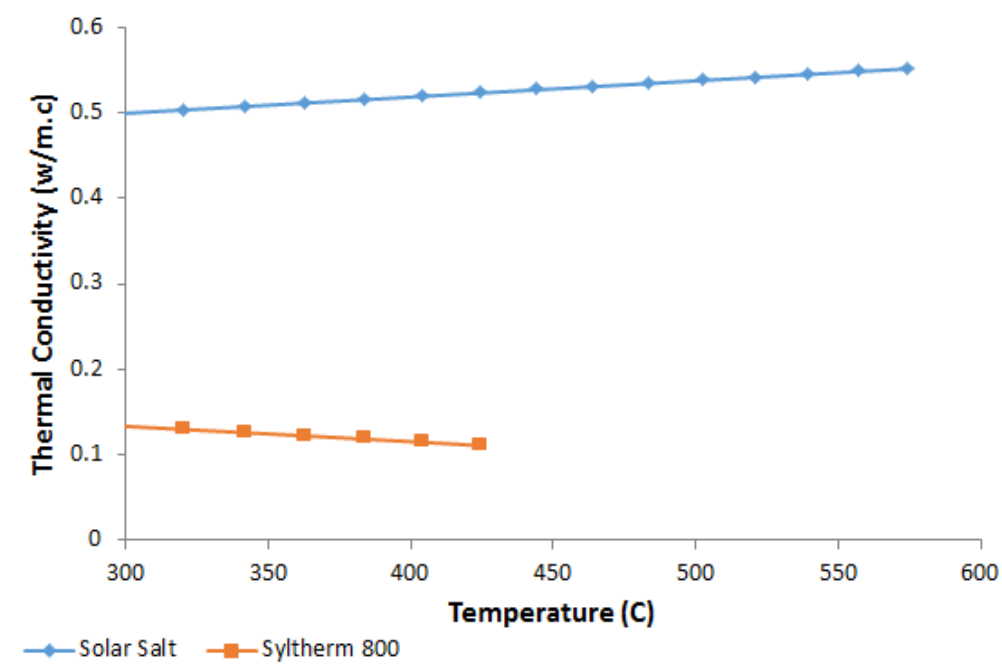

Figure (15) Hitec Solar Salt thermal conductivity with temperature vs. Syltherm 800

As the efficiency of the collector is strongly related to the mass flow rate of the fluid in the absorber pipe, SAM gives many values of mass flow rates and deduced how much flow rate influences the efficiency see figure (16). It has been noted from simulation findings that the more mass flow rate increases the higher the efficiency due to the fact that the residence time of the fluid inside the pipe is longer thus it collects more heat from the pipe but also allows long time for losses due to this fact efficiency decreases, so that the mass flow rate will be adjust around the day to maintain the fluid remaining inside the pipe to collect more heat and lead to more efficiency. Figure (17) shows that the mass flow rate increased to get the maximum value as we approach the middle of the day.

The Average HTF temperatures above ambient analyzed as exemplified in figure (18), we note that the average HTF temperature above ambient is higher in the winter than the summer, where the heat losses are lower in the winter than the summer. This is because the plants typically operate at lower HTF temperatures during the winter. 


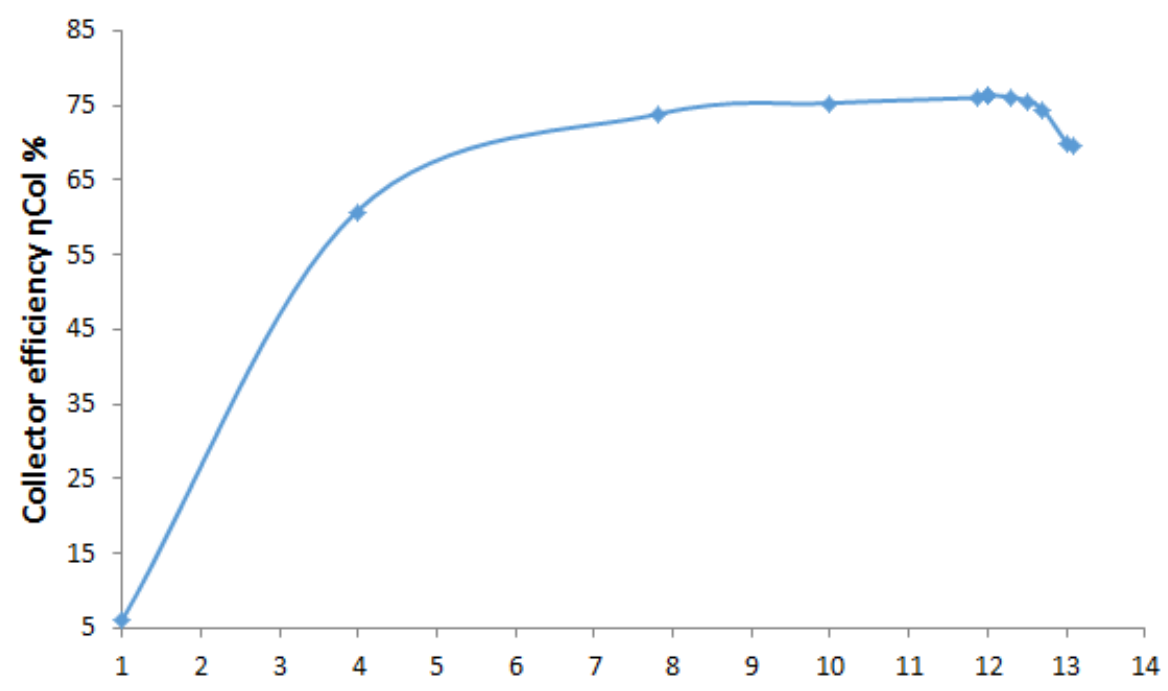

Figure (16) Mass flow rate influence on the collector efficiency

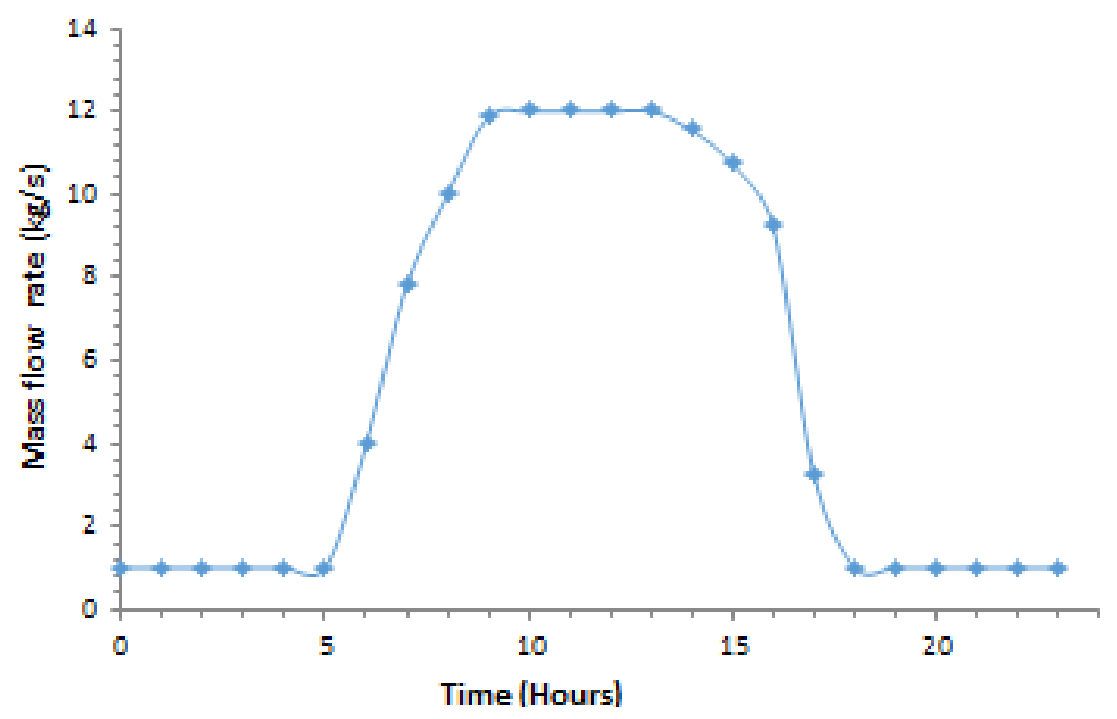

Figure (17) Mass flow rate (kg/s) with time

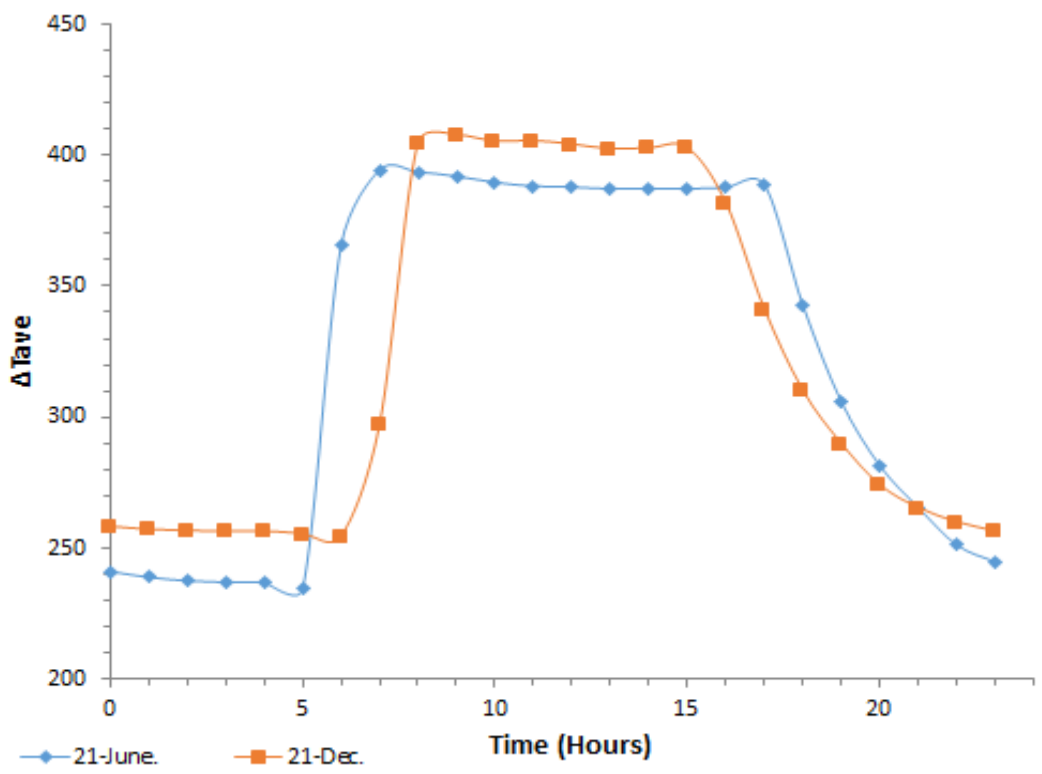

Figure (18) Average HTF temperatures above ambient with time 
The monthly mean daily heat gain of the solar salt is determined for the three cities in Egypt (Aswan, El-Giza and Marsa Matruh. Figure (19) reveals that the selection of HTF affects heat gain and the HCE thermal performance in the different locations. On the other hand, the monthly mean daily heat gain is influenced by the climatic conditions of each site like the DNI, the ambient temperature and the wind speed. We observe also from Figure (19) that the heat gain received by the solar salt is the best for Aswan city in July to reach $3.67 \times 10^{11}$ $\left(\mathrm{J} / \mathrm{m} /\right.$ day) and reaches to $3.48 \times 10^{11}(\mathrm{~J} / \mathrm{m} /$ day $)$ and $3.45 \times 10^{11}(\mathrm{~J} / \mathrm{m} /$ day $)$ in the same month for El-Giza and Marsa Matruh respectively. It is noticed that the summer season (high DNI) has the most important monthly mean daily heat gain for the different selected sites.

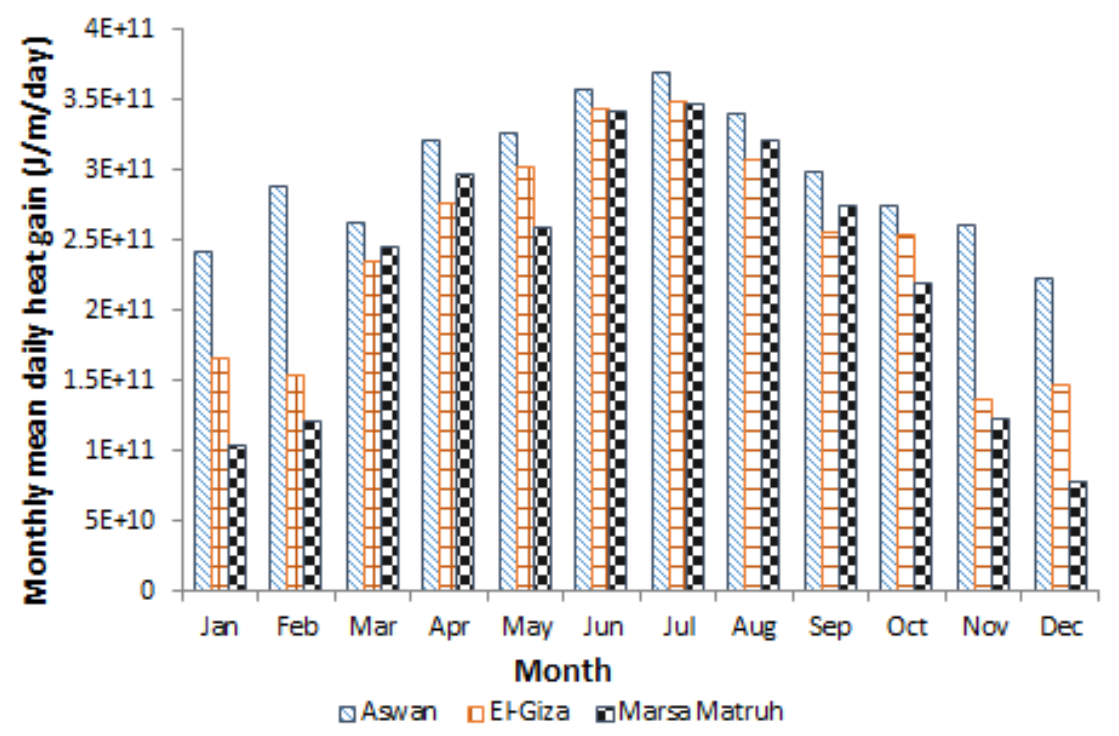

Figure (19) Monthly mean daily heat gain of solar salt for the selected locations in Egypt.

\section{- Results Validation}

In order to validate the numerical results of this study, we use the literature data available in references [13,15\&25] and data available in NREL (National Renewable Energy Laboratory) [5], where these data are used for validation and comparing purposes in several studies with different scenarios and topographical conditions. For convenience all figures along with general comments for comparison are listed in Table (2).

Table (2) List of Figures, Comments and comparison with the literature data available in references

\begin{tabular}{|c|l|l|}
\hline Figure & \multicolumn{1}{|c|}{ Description } & \multicolumn{1}{c|}{ Comments } \\
\hline$(1 \& 2)$ & $\begin{array}{l}\text { Clear-day direct solar irradiance } \\
\text { for two axes tracking system }\end{array}$ & $\begin{array}{l}\text { The results in these figures compared with the data from Ref. [13 \&25], } \\
\text { which included different topographical and climatic conditions, we can } \\
\text { find that the finding results have better agreement with very small } \\
\text { deviation not more than 0.2\%. }\end{array}$ \\
\hline$(3 \& 4)$ & $\begin{array}{l}\text { Monthly mean daily direct solar } \\
\text { radiation for two axis tracking }\end{array}$ & $\begin{array}{l}\text { These two figures compared with the data in Ref. [25]. The atmospheric } \\
\text { conditions are for Algeria and the finding results for the present study } \\
\text { gave good accuracy. }\end{array}$ \\
\hline
\end{tabular}


Table (2) Continue

\begin{tabular}{|c|c|c|}
\hline$(8 \& 9)$ & $\begin{array}{l}\text { Hitec solar salt, absorber and } \\
\text { glass envelope temperatures } \\
\text { over time (Hour) }\end{array}$ & $\begin{array}{l}\text { The two figures compared with the data in Ref. [15 \& 25]. The chosen } \\
\text { collector for Ref. [25] is of LS- } 2 \text { type with two axis tracking system and } \\
\text { with a vacuum in the annulus space between the absorber and the glass } \\
\text { envelope. The Syltherm } 800 \text { is the HTF used in it and used and a global } \\
\text { algorithm, developed under FORTRAN language, is used. Our finding } \\
\text { results showed very good accuracy with very small deviation. }\end{array}$ \\
\hline$(10 \& 11)$ & $\begin{array}{l}\text { Heat gain and heat loss over } \\
\text { time (Hour) }\end{array}$ & $\begin{array}{l}\text { Heat gain and heat loss results are validated with the data from the Ref. } \\
{[5,13 \& 25] \text {. The collector used for them are LS- } 2 \text { type using different }} \\
\text { HTF(s). Ref.[5 \&13] use the EES programs to get the results and the } \\
\text { finding results in our study compared to them results have a deviation } \\
\text { not more than } 10 \% \text {. }\end{array}$ \\
\hline$(12-15)$ & $\begin{array}{l}\text { The thermal behavior of the } \\
\text { solar salt with temperature }\end{array}$ & $\begin{array}{l}\text { The four figures represent the thermal behavior of the solar salt with } \\
\text { temperature. We noticed from these figures that the four physical } \\
\text { properties (Density, specific heat, viscosity and thermal conductivity) } \\
\text { influence the temperature evolution of the fluid. The solar salt used in } \\
\text { our study has maximum range of temperature compared to the thermal } \\
\text { oils used in Ref. [5,13 \&25], so the solar salt has the most important } \\
\text { density and thermal conductivity. }\end{array}$ \\
\hline (16) & $\begin{array}{l}\text { Mass flow rate influence on } \\
\text { the collector efficiency }\end{array}$ & $\begin{array}{l}\text { SAM gives many values of mass flow rates and deduced how much flow } \\
\text { rate influences the efficiency. Comparing the finding results with the } \\
\text { data available in Ref. [ } 5 \text { \& } 13 \text { ] we can find that our simulated results are } \\
\text { relatively accurate with small deviation and our collector gave more } \\
\text { efficiency than others. }\end{array}$ \\
\hline$(17)$ & Mass flow rate $(\mathrm{kg} / \mathrm{s})$ with time & $\begin{array}{l}\text { Mass flow rate increased to get the maximum value as we approach the } \\
\text { middle of the day then it decreased in the afternoon until sunset. SAM } \\
\text { increases the value of the HTF mass flow rate to absorb more heat along } \\
\text { the pipes. }\end{array}$ \\
\hline$(18)$ & $\begin{array}{l}\text { Average HTF temperatures } \\
\text { above ambient with time } \\
\text { (Hour) }\end{array}$ & $\begin{array}{l}\text { The results given from SAM comparing to other simulation models in } \\
\text { the literature references prove that our results is more accurate and } \\
\text { reliable. }\end{array}$ \\
\hline (19) & $\begin{array}{l}\text { Monthly mean daily heat gain } \\
\text { of solar salt for the selected } \\
\text { locations in Egypt }\end{array}$ & $\begin{array}{l}\text { Comparing the results in this figure with the counterpart existing in Ref. } \\
\text { [25] for Algeria which included different topographical and climatic } \\
\text { conditions, we can find that the finding results have good agreement } \\
\text { with very small deviation not more than } 1 \% \text {. }\end{array}$ \\
\hline
\end{tabular}

\section{- Validation conclusion:}

As shown above, the deviation percentage between our finding results and the results of the available literature data in references doesn't exceed 10\%. Tis minor deviation proves that the research model is highly accurate with reliable results. 


\section{Conclusions}

Increasing energy demand and growing environmental problems due to the use of fossil fuels, parabolic trough solar thermal power plants technologies offer interesting opportunities for the country. Egypt has favorable climatic conditions for the construction of parabolic trough solar thermal power plants. A mathematical model considering the geometrical, optical, thermal and fluid dynamic aspects of a solar PTC has been carried out. The accuracy of the detailed simulation model using SAM is demonstrated in this paper by the simulation of the change of the temperature and heat gain of the solar salt, change of the temperature of the absorber and the envelope during period of daylight for typical days. The results shown that the solar salt can operate at high temperature more than $550^{\circ} \mathrm{C}$. The simulation of the annual monthly mean heat gain in the three locations selected from Egypt shown that Aswan city has the best annual monthly mean heat gain compared to another. Moreover, it is important to state that this model proves its validity for using in many other studies.

\section{REFRENCE}

[1] Trabea, A.A., 2000. Analysis of solar radiation measurements at Al-Arish area, North Sinai, Egypt. Renewable Energy, 20(1): 109-125.

[2] ZekiYılmazoglu M, Durmaz A, Baker D. Solar repowering of Soma-A thermal power plant. Energy Convers Manage 2012;64:232-7.

[3] Stoddard L, Abiecunas J, O'Connell R. Economic, energy, and environmental benefits of concentrating solar power in California, National Renewable Energy Laboratory, subcontract report NREL/SR-550-39291, April 2006.

[4] Mariam G. Salim, 2012. Selection of groundwater sites in Egypt, using geographic information systems, for desalination by solar energy in order to reduce greenhouse gases. Journal of Advanced Research, 3(1): 11-19.

[5] Forristall R. Heat transfer analysis and modeling of a parabolic trough solar receiver implemented in engineering equation solver. National Renewable Energy Laboratory (NREL); 2003.

[6] Garcia-Valladares O, Velazquez N. Numerical simulation of parabolic trough solar collector: improvement using counter flow concentric circular heat exchangers. Int J Heat Mass Trans 2009;52(3-4):597-609.

[7] He Y, Xiao J, Cheng Z, Tao Y. A MCRT and FVM coupled simulation method for energy conversion process in parabolic trough solar collector. Renew Energy 2011;36:976-85.

[8] Padilla Ricardo Vasquez, Demirkaya Gokmen, Yogi Goswami D, Stefanakos Elias, Rahman Muhammad M. Heat transfer analysis of parabolic trough solar receiver. Appl Energy 2011;88:5097-110.

[9] Lei Dongqiang, Li Qiang, Wang Zhifeng, Li Jian, Li Jianbin. An experimental study of thermal characterization of parabolic trough receivers. Energ Convers Manage 2013;69:107-15. [10] Cheng ZD, He YL, Cui FQ, Xu RJ, Tao YB. Numerical simulation of a parabolic trough solar collector with nonuniform solar flux conditions by coupling FVM and MCRT method. Sol Energy 2012;86(6):1770-8. 
[11] Nagarjuna Reddy, C. and Harinarayana, T., 2015. Solar Thermal Energy Generation Potential in Gujarat and Tamil. Nadu States, India. Energy and Power Engineering, 7, 591-603. http://dx.doi.org/10.4236/epe.2015.713056

[12] Jignasha Bhutka, Jaymin Gajjar, T. Harinarayana, 2016. Modelling of Solar Thermal Power Plant Using Parabolic Trough Collector. Journal of Power and Energy Engineering, 2016, 4, 9-25 [13] Charlain-Joel Ngangoum Keou, Donatien Njomo1, Vincent Sambou, A. R. Andrianaharinjaka Finiavana, Ahmadou Diaby Tidiane, 2017. Two-Dimension Numerical Simulation of Parabolic Trough Solar Collector: Far North Region of Cameroon. Energy and Power Engineering, 2017, 9, 147-169. http://www.scirp.org/journal/epe [14] Evangelos Bellos and Christos Tzivanidis, 2018. Analytical Expression of Parabolic Trough Solar Collector Performance. Designs 2018, 2, 9; doi:10.3390/designs2010009. www.mdpi.com/journal/designs [15] Zouhir Leemrani, Salma Marrakchi, Hassan Asselman, Adel Asselman, 2018. The study of the performance of a parabolic trough collector in the region of north-west of Morocco. www.sciencedirect.com

[16] Mohammed Hasan Abbood, Mohammed Mohsen Mohammed, 2019. Experimental characteristic of a solar parabolic trough collector with indirect steam generation system. Volume 10, Issue 2, 2019 pp.87-96 Journal homepage: www.IJEE.IEEFoundation.org

[17] T. Markvart, Solar electricity. 2nd ed. New York: John Wiley and Sons Inc.; 1996. [18] A. Hossein Mousazadeh, A. Alireza Keyhani, B. Arzhang Javadi, A. Hossein Mobli, C. Karen Abrinia, B. Ahmad Sharifi. A review of principle and suntracking methods for maximizing solar systems output. Renewable and Sustainable Energy Reviews 13; 2009, 1800-1818 [19]Forristall R. Heat transfer analysis and modeling of a parabolic trough solar receiver implemented in engineering equation solver. National Renewable Energy Laboratory (NREL); 2003.

[20] Incropera F, DeWitt D. Fundamentals of heat and mass transfer, 6th ed.; 1990.

[21] Gnielinski V. New equations for heat and mass transfer in turbulent pipe and channel flow. Int Chem Eng 1976;16(2):359-63.

[22] KJC Operating Company. " Final Report on HCE Heat Transfer Analysis Code". SANDIA Contract No. AB-0227. Albuquerque, NM: Sandia National Laboratories (December 1993) [23] S. Klein. Engineering Equation Solver (EES) for Microsoft Windows Operating System: Commercial and Professional Versions. Online at www.fchart.com, 2010 [24] Quoilin S. Concentrator solar power plants (en Francais). Faculty of Applied Sciences, University of Liege; 2007.

[25] Ouagued, M., Khellaf, A. and Loukarfi, L. (2013) Estimation of the Temperature, Heat Gain and Heat Loss by Solar Parabolic Trough Collector under Algerian Climate Using Different Thermal Oils. Energy Conversion and Management, 75,191-201. 